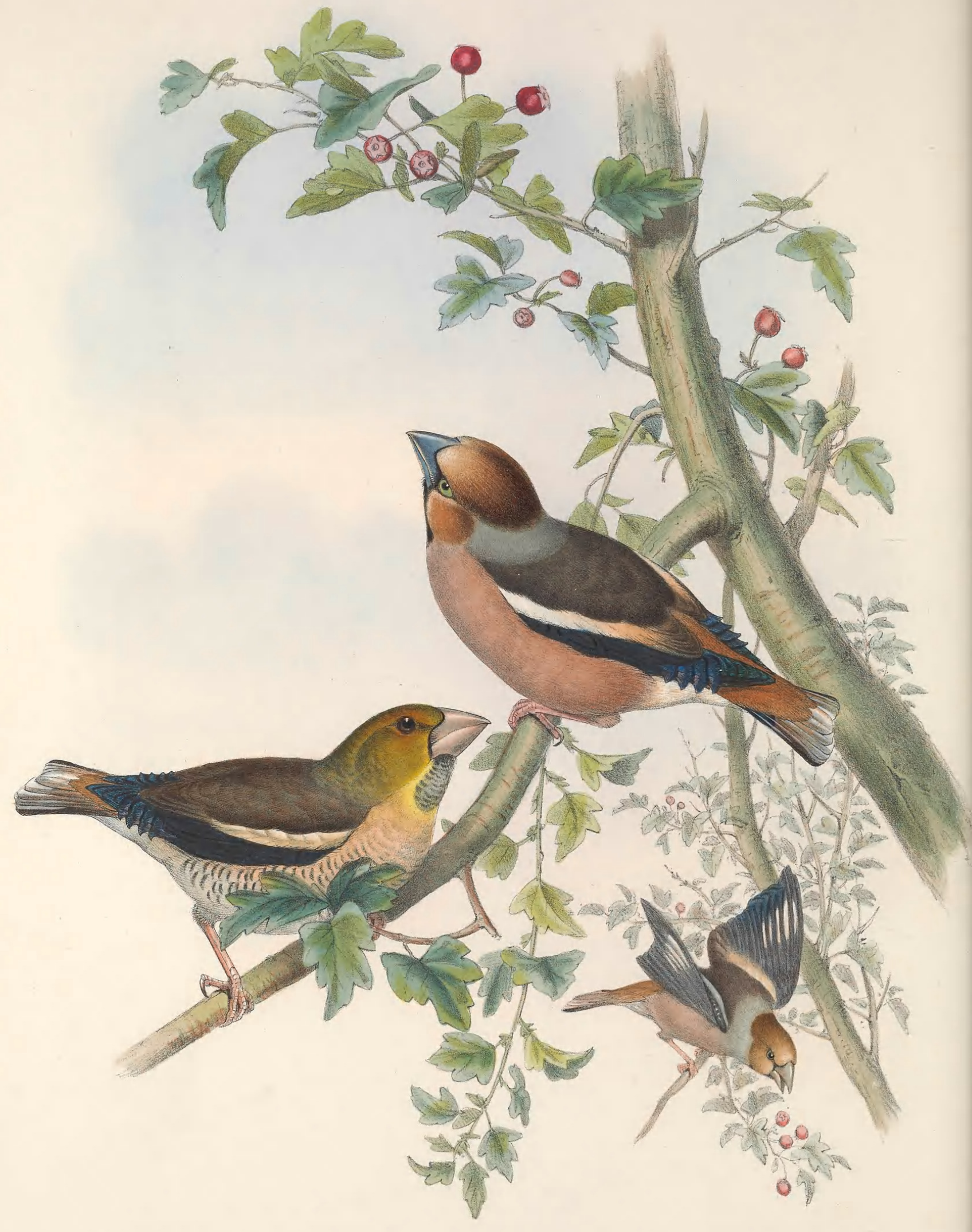




\section{COCCOTHRAUSTES VULGARIS.}

\section{Hawfinch.}

Loxia coccothraustes, Linnæus, Gmelin, \&c.

Fringilla coccothraustes, Temminck.

Coccothraustes vulgaris, Fleming, Selby, \&c.

deformis, Koch.

atrigularis, Macgillivray.

THE Hawfinch, or Grosbeak, as it is frequently called, is by far the largest of the Fringillide inhabiting Great Britain, where it is a constant resident. Although somewhat local, it is far more generally dispersed over the country than was formerly supposed. Mr. Rodd mentions it in his 'List of Cornish Birds ;' but it appears to be less common in Cornwall than in many other parts of England. In Sussex, Surrey, Kent, Middlesex, and Essex it is very abundant, and, although the northern counties are not without its presence, it gradually becomes less numerous towards the north; it is, however, found in the southern parts of Scotland. In Ireland it is certainly not so numerous as in England, but still it is far from rare in that country. The Rev. F. O. Morris, after enumerating the several parts of Ireland in which it has been found, says, "But in the Phœenix Park, near Dublin, where the hawthorn-trees are both among the finest and in the greatest numbers I have ever seen, it appears to be procurable in small numbers every winter." On the continent of Europe it is, I believe, not too much to say that it is universally dispersed, except in the extreme northern parts. It was met with in the eastern Atlas of North Africa by Mr. Salvin; and I have specimens in my collection which were procured in Asia Minor. This, however, is not the extent of its range in an easterly direction ; for, although it does not form part of the avi-fauna of India, strange to say, it is one of the very commonest birds of the Amoor, China, and Japan, as is evidenced by the numerous examples sent home from those countries. So precisely do Chinese specimens accord with those killed in Britain, that I am quite unable to detect even such a slight variation between them as would be sufficient to constitute them a different race.

For the best account of the habits of the Hawfinch we are indebted to the pen of Mr. Henry Doubleday, of Epping, a gentleman well known as a lover of nature, and a keen observer of our native birds. In his paper on the subject, published in the first volume of the 'Magazine of Zoology and Botany,' he says, "I have for some years given close attention to their habits, and I can safely assert that they are permanent residents; nor can I perceive any addition to their numbers by the arrival of foreigners at any period of the year. Their extreme shyness has, no doubt, contributed to keep us in ignorance of their habits and economy; in this trait they exceed any land-bird with which I am acquainted, and in open places it is almost impossible to approach them within gunshot. Their principal food here appears to be the seed of the hornbeam (Carpinus betulus, Linn.), which is the prevailing species of tree in Epping Forest; they also feed on the kernels of the haws, plum-stones, laurel-berries, \&c., and in summer make great havoc amongst green peas in gardens, in the vicinity of the forest.

"About the middle of April they pair, and in a week or two commence nidification. The situation of the nest is various, but it is most commonly placed in an old scrubby white-thorn bush, often in a very exposed situation; they also frequently build on the horizontal arms of old oaks, the heads of pollard hornbeams, in hollies, and occasionally in fir-trees in plantations, the elevation at which the nest is placed varying from five to twenty-five or thirty feet. The most correct description of the nest which I have seen is in Latham's 'Synopsis.' It is there said to be composed of the dead twigs of oak, honeysuckle, \&c., intermixed with pieces of grey lichen : the quantity of this last material varies much in different nests, but it is never absent; in some it is only very sparingly placed among the twigs, in others the greater part of the nest is composed of it: the lining consists of fine roots and a little hair. The whole fabric is very loosely put together, and it requires considerable care to remove it from its situation uninjured."

A nest taken from a tall white-thorn by Joseph Gurney Barclay, Esq., who resides at Leighton, near Epping Forest, is described by Mr. Yarrell as being " formed of twigs laid across the branches, in various directions, as a framework or foundation of support; and the whole of the upper part was composed of gardeners' bass, wreathed in circles, and mixed with a few fine roots." Another nest brought to Mr. Yarrell "had a flat under surface of dead twigs of fir and birch, nearly as thick as wheat-straw, with fibrous roots and grey lichen laid flat upon them, the structure resembling the platform-nests made by Doves and Pigeons."

"The eggs," says Mr. Doubleday, "vary in number from four to six, and are of a pale olive-green, spotted with black, and irregularly streaked with dusky grey. Some specimens are far less marked than others, and I have seen some of a uniform pale green; their length is eleven lines by eight lines and a half in breadth. 
"The young are hatched about the third week in May; and as soon as they are able to provide for themselves, they unite with the old birds, in flocks varying in number from fifteen or twenty to one hundred, or even to two hundred individuals. In this manner they remain through the winter, feeding on the hornbeamseeds which have fallen to the ground, the newly cracked shells of which are to be seen in abundance at their haunts; the birds only separate at the approach of the breeding-season. I believe the male has no song worth notice; in warm days in March I have heard them, when a number have been sitting together on a tree, uttering a few notes in a soft tone, bearing some resemblance to those of the Bullfinch."

So close does this bird approach to London, that Mr. Yarrell mentions he has known it to be killed at Notting Hill; and Mr. Jesse states that it breeds at Roehampton. My own acquaintance with it has been chiefly in the charming woods of the Duchess of Sutherland, at Cliveden in Buckinghamshire, and the contiguous beautiful gardens of Formosa. As at Epping, the bird may here be seen at all seasons, but in far less numbers. I might mention many other localities where it may be found, such as the pleasure-grounds of W. Wells, Esq., at Redleaf in Kent, Windsor Great Park, \&c. ; but it will be sufficient to say that wherever there are trees bearing its favourite food, there will the bird be found, especially in the midland counties of England.

The Hawfinch is a stout, thick-set, and inelegant bird, its inelegance being rendered more conspicuous by the enormous size of its bill and head when compared with that of its body and short square tail ; still Nature has attempted some degree of ornamentation in the purplish-green colouring and in the truncate and partially curled form of its secondaries; the form of these feathers at their extremities is indeed very remarkable, and not to be seen in any other bird. It bears confinement well, and, according to Bechstein, "will feed upon rape and hemp-seed directly they are caught, and should be chiefly fed upon those seeds, with fruit and green food." Montagu states that even in winter, during mild weather, he has heard the Hawfinch sing sweetly, in low and plaintive notes; and Mr. Selby thinks it probable that it sings well in the pairing-season; but Bechstein says, "For my part I cannot endure the unpleasant shrill call of its zip, which it incessantly utters ; nevertheless its song, which consists of a light jingle with some shrill and harsh notes like irrr, is agreeable enough to many amateurs."

The sexes, when adult, vary in the colouring of their plumage, and they are also subject to a seasonal change in the hue of the bill, that organ being nearly white in winter, while in summer it is of a rich blue, sometimes uniform, at others relieved by a grey band round the base of the mandibles; the rich blue colouring is common to both sexes, but the under mandible of the female is frequently white, while the upper one is blue; the legs are either fleshy white or reddish flesh-colour, and the irides are greyish white.

The young Hawfinch, just before it is able to fly, has the bill light olive inclining to pea-green, with a tinge of orange at the base, the legs purplish brown, and the irides dark brown. At this age the wings and tail have begun to assume their adult colouring; but the plumage of the body has a very mottled appearance, a considerable amount of grey being mixed up with the commencement of the colours of maturity; the cheeks and throat are stained with yellow, and the tips of the breast-feathers are marked with brown. A young bird in this state was taken in Mr. De Vitré's garden of Formosa, in Berkshire, on the 11th of June, 1859.

The young of the first year, when fully as large as the adult, has the bill of a nearly uniform light-purplish flesh-colour, the irides brown, and the tarsi and toes pinky-red. The assumption of the adult colouring has further advanced, but the body still wears a mottled appearance; the black feathers of the throat begin to show, and the cheeks and breast are of a still richer yellow. A specimen thus coloured was taken on the 5 th of August.

The male has the forehead light greyish buff gradually deepening into the rich chestnut of the crown, sides of the head, and occiput; at the back of the neck a broad collar of grey ; back, scapularies, and lesser wingcoverts deep chocolate-brown; lower part of the back and upper tail-coverts cinnamon-brown; frontal half of the greater wing-coverts greyish white, the posterior half pale brown; spurious wing and primaries deep black, their inner webs crossed near the middle by a broad mark of pure white, and the third and fourth glossed with green at the tip of the same web; secondaries purplish green, their inner webs crossed near the middle with a broad mark of pure white; tail black, largely tipped on the inner webs with white, the black of the apical portion of the outer web gradually becoming paler as the feathers approach the centre; lores, a narrow line down each side of the bill, and a large patch on the centre of the throat velvety black; cheeks light orange-brown; under surface vinaceous brown, fading into greyish white in the vent and under tailcoverts.

The female differs in having only a trace of the chestnut colouring of the head on the occiput, the grey collar less defined, and the back of a chestnut instead of a deep-chocolate tint; the black throat-mark, too, is not so conspicuous, and the general tints are altogether paler.

The Plate represents an adult male in the summer plumage, a young bird about a month old, and a reduced figure of the male in the winter dress. 


\section{$2 \mathrm{BHL}$ Biodiversity Heritage Library}

Gould, John. 1873. "Hawfinch, Coccothraustes vulgaris [PI. 40]." The birds of Great Britain 3, -. https://doi.org/10.5962/p.323931.

View This Item Online: https://www.biodiversitylibrary.org/item/221726

DOI: https://doi.org/10.5962/p.323931

Permalink: https://www.biodiversitylibrary.org/partpdf/323931

\section{Holding Institution}

Smithsonian Libraries

\section{Sponsored by}

Biodiversity Heritage Library

\section{Copyright \& Reuse}

Copyright Status: Public domain. The BHL considers that this work is no longer under copyright protection.

This document was created from content at the Biodiversity Heritage Library, the world's largest open access digital library for biodiversity literature and archives. Visit BHL at https://www.biodiversitylibrary.org. 